\title{
Role of $\mathrm{LH}$ pulse amplitude and the rate of $\mathrm{LH}$ increase on oestradiol-17 $\beta$ secretion by immature rat ovaries in perfusion culture
}

\author{
J. J. Peluso and R. W. Steger* \\ Department of Obstetrics and Gynecology, University of Connecticut Health Center, Farmington, \\ CT 06032, and * Department of Physiology, Southern Illinois University, Carbondale, IL 62901, \\ U.S.A.
}

\begin{abstract}
Summary. Immature rat ovaries were placed in perifusion culture and exposed to LH in a variety of patterns, while tonic levels of FSH $(200 \mathrm{ng} / \mathrm{ml})$ were maintained. Perifusate was collected every $5 \mathrm{~min}$ and assayed for oestradiol-17 $\beta$. In Exp. I, LH was delivered at $50 \mathrm{ng} / \mathrm{ml}$ for $30 \mathrm{~min}$ then reduced to $0 \mathrm{ng} / \mathrm{ml}$ for an additional $30 \mathrm{~min}(50 \mathrm{ng} / \mathrm{ml} \mathrm{LH}$ step) or as linear increasing concentrations reaching $50 \mathrm{ng} / \mathrm{ml}$ by $30 \mathrm{~min}$ of culture then linear decreasing concentrations reaching $0 \mathrm{ng} / \mathrm{ml}$ by $30 \mathrm{~min}$ of culture $(50 \mathrm{ng} / \mathrm{ml} \mathrm{LH}$ ramp). Although both delivery systems exposed the tissue to $250 \mathrm{ng}$ LH over the 1-h culture period, only the $50 \mathrm{ng} / \mathrm{ml}$ step significantly increased oestradiol-17 $\beta$ secretion rates $(P<0.05)$. In Exp. II, ovaries were not exposed to $\mathrm{LH}$ for the first $30 \mathrm{~min}$ of culture but then $\mathrm{LH}$ was administered at a concentration of 25 or $50 \mathrm{ng} / \mathrm{ml}$ for $30 \mathrm{~min}$. The $\mathrm{LH}$ concentration was reduced to $0 \mathrm{ng} / \mathrm{ml}$ for an additional $30 \mathrm{~min}$ of culture. Oestradiol- $17 \beta$ secretion rates were increased $50 \%$ by both treatments. These results suggest that the mechanism by which an LH pulse stimulates the immature ovary to secrete oestradiol-17 $\beta$ is, in part (1) 'threshold'-dependent and not solely dependent on the amount of $\mathrm{LH}$ administered, and (2) dependent on the time required to achieve a 'threshold' level.
\end{abstract}

\section{Introduction}

As rats approach puberty, mean LH concentrations increase (Meijs-Roelofs et al., 1983). During the transition from the juvenile to the peripubertal stage, LH is secreted in a pulsatile pattern (Andrews \& Ojeda, 1981; Kimura \& Kawakami, 1982; Urbanski \& Ojeda, 1985b). Although the frequency of these pulses remains relatively constant at about one every $30 \mathrm{~min}$, an increase in the amplitude of each LH pulse ultimately accounts for the increase in the overall mean LH values (Urbanski \& Ojeda, 1985b).

LH (hCG) receptors are observed in the interstitial and theca cells of the prepubertal ovary by 10 days of age and in the granulosa cells of some antral follicles by 21 days of age (Peluso et al., 1976; Uilenbroek \& van der Linden, 1983). The increase in mean LH values, presumably acting through ovarian LH receptors, stimulates oestrogen secretion (Quattropani \& Weisz, 1973; Lamprecht et al., 1976) and follicular growth (Richards \& Bogovich, 1982) within the immature ovary.

When immature rat ovaries are placed in perifusion culture, the secretion of both oestradiol-17 $\beta$ and progesterone is increased by exposure to tonic levels of LH (Urbanski \& Ojeda, 1985a). Discontinuous or pulsatile LH exposure also enhances steroid secretion from the immature ovary. The amount of steroid secreted in response to continuous or pulsatile LH is similar as long as the amplitude of the $\mathrm{LH}$ pulse is equal to the $\mathrm{LH}$ concentration of the continuous stimulation 
(Urbanski \& Ojeda, 1985a). Since the amount of LH in the pulsatile treatment is several times less than in the continuous treatment, this observation reinforces the concept that LH must reach a 'threshold' concentration in order to evoke a stimulatory response. A similar relationship between LH and oestradiol secretion has been observed for the adult rat ovary (Peluso et al., 1984a, b) and isolated rabbit (D'Amato et al., 1981) and preovulatory rat (Hedin et al., 1983) follicles.

It is clear that exposure to LH pulses stimulate physiological responses from the ovaries of immature and mature rats. However, the characteristics of the LH pulse which convey its stimulatory action have not been defined. A single LH pulse can be broken down into two major components: amplitude and the time required to reach an amplitude. The present study was designed to evaluate the contributions of each of these pulse characteristics on the ability of an LH pulse to stimulate oestradiol secretion from the immature ovary.

\section{Materials and Methods}

Preparation of culture medium. Ovine luteinizing hormone (NIAMDD-oLH-23) and ovine follicle-stimulating hormone (NIAMDD-oFSH-14) were used in these experiments. LH contamination of the ovine FSH preparation was $0.04 \times$ ovine LH-S-1. In a $200 \mathrm{ng}$ FSH-RP-1 equivalent dose there were $27 \mathrm{ng}$ LH-RP-1 activity. Stock solutions were prepared by dissolving $10 \mathrm{mg}$ of each gonadotrophin in $10 \mathrm{ml}$ Medium-199. Each gonadotrophin was mixed separately and frozen at $-20^{\circ} \mathrm{C}$ for up to 3 months until added to culture media. LH and FSH concentrations in the final solutions were expressed in RP-1 units. The amount of LH within the medium referred to the amount of LH activity due to the ovine LH preparation and does not include the $27 \mathrm{ng} \mathrm{LH}-\mathrm{RP}-1$ units of activity of the ovine FSH preparation which was present in all the media.

Gonadotrophins were added to Medium 199 which was supplemented with $2 \cdot 2 \mathrm{~g} \mathrm{NaHCO}_{3} / 1,2 \mathrm{~g} \mathrm{BSA} / 1,50 \mathrm{mg}$ streptomycin sulphate/1, 62.9 mg K-penicillin-G/1, 2.38 g Hepes/I and insulin (200 i.u./l; Lente Iletin I, Eli Lilly, Indianapolis, IN). The $\mathrm{pH}$ of the medium was adjusted to $7 \cdot 4$.

Animals. Immature (21 days old) female Wistar rats were obtained from Charles Rivers Laboratory, and housed under controlled conditions of temperature, humidity, and photoperiod $(12 \mathrm{~h} \mathrm{light} / 12 \mathrm{~h}$ dark; lights on at 07:00 h). The rats were used when they were 30-32 days of age. On the day of the experiment, they were decapitated between 09:00 and 12:00 $\mathrm{h}$ and both ovaries were removed. The ovaries were trimmed of fat and placed in oxygenated medium supplemented with $200 \mathrm{i}$.u. insulin/l and $400 \mathrm{i}$.u. heparin/l. After $10-15 \mathrm{~min}$ individual ovaries were placed in a $200 \mu \mathrm{l}$ microchamber (Endotronics, Inc., Minneapolis, MN). The microchambers were placed in a water-jacketed chamber designed to maintain the microchambers at $37^{\circ} \mathrm{C}$ during perifusion. The medium flow rate through each of the microchambers was $10 \mathrm{ml} / \mathrm{h}$. The medium was continuously gassed with $5 \% \mathrm{CO}_{2}$ in oxygen throughout the culture. Perifusate was collected every $5 \mathrm{~min}$. The perifusate was frozen, stored at $-20^{\circ} \mathrm{C}$ and subsequently assayed for oestradiol-17ß.

The culture system. The Acusyst 1000 culture instrument (Endotronics, Inc.) used in these studies is a computercontrolled perifusion culture system which delivers regulatory agents to culture chambers by controlling various peristaltic pumps. The Acusyst software also performed all the mathematical modelling necessary to produce the desired delivery patterns of LH. The mathematical model has been previously described (Gruenberg et al., 1983).

Experimental design. In Exp. I, immature ovaries were perifused with medium containing $200 \mathrm{ng} \mathrm{FSH} / \mathrm{ml}$ and LH delivered (1) at a concentration of $50 \mathrm{ng} / \mathrm{ml}$ for the first $30 \mathrm{~min}$ then decreased to $0 \mathrm{ng} / \mathrm{ml}$ for the remaining $30 \mathrm{~min}$ (50 ng/ml LH step) or (2) as an ascending and descending ramp in which, for the first $30 \mathrm{~min}$, LH concentrations increased linearly, reaching a peak of $50 \mathrm{ng} / \mathrm{ml} ; \mathrm{LH}$ concentration then decreased linearly to $0 \mathrm{ng} / \mathrm{ml}$ by $60 \mathrm{~min}$ of culture $(50 \mathrm{ng} / \mathrm{ml} \mathrm{LH} \mathrm{ramp})$. In both treatments, FSH $(200 \mathrm{ng} / \mathrm{ml})$ was always present and a total of $250 \mathrm{ng} \mathrm{LH}$ was delivered. A group of ovaries was perifused with FSH alone $(200 \mathrm{ng} / \mathrm{ml})$ and served as a control group.

For Exp. II, immature ovaries were perifused for $30 \mathrm{~min}$ with tonic FSH $(200 \mathrm{ng} / \mathrm{ml})$. At $30 \mathrm{~min} \mathrm{LH}$ concentration was increased to 25 or $50 \mathrm{ng} / \mathrm{ml}$. LH concentration remained at the respective elevated value until 30 min of culture when it was reduced to $0 \mathrm{ng} / \mathrm{ml}$. The cultures were continued for an additional $30 \mathrm{~min}$. FSH was present in the medium throughout the culture period.

Oestradiol-17 $\beta$ assay. Oestradiol-17 $\beta$ was assayed using a direct double-antibody radioimmunoassay (Radioassay Systems Laboratory, Carson, CA). The antiserum to oestradiol- $17 \beta$ cross-reacts $100 \%$ with oestradiol- $17 \beta, 15 \%$ with oestrone and $<0.01 \%$ with several other steroids. The assay sensitivity was $30 \mathrm{pg} / \mathrm{ml}$. All samples were assayed in duplicate. The intra- and interasssay coefficients of variation were $8.3 \%$ and $12.9 \%$, respectively.

Statistical analysis. Oestradiol- $17 \beta$ values were expressed as a percentage of control values. The data generated in Exp. I were analysed by analysis of variance followed by Student-Newman-Keuls multiple range test. The data from Exp. II were evaluated using paired Student's $t$ tests. Regardless of the mode of analysis only $P$ values $\leqslant 0.05$ were considered to be significant. 


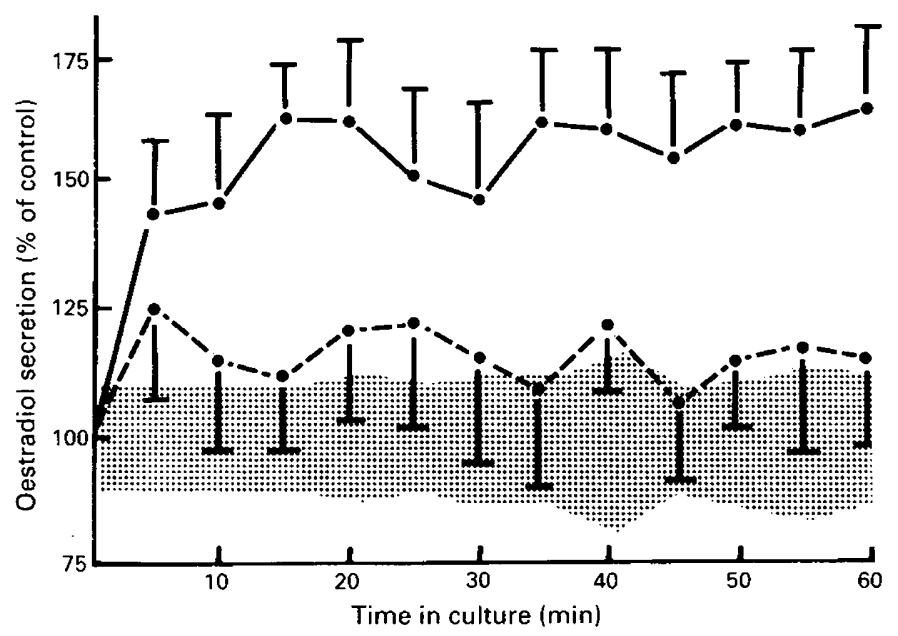

Fig. 1. The percentage change in oestradiol-17 $\beta$ secretory rates (means \pm s.e.m.) for ovaries cultured with a $50 \mathrm{ng} / \mathrm{ml} \mathrm{LH} \mathrm{step} \mathrm{(-C)} \mathrm{or} \mathrm{a} 50 \mathrm{ng} / \mathrm{ml} \mathrm{LH} \mathrm{ramp} \mathrm{(--}$ oestradiol-17 secretion rates for the controls are shown in the stippled area. The average oestradiol- $17 \beta$ secretion rate for the control was $2.14 \pm 0.02 \mathrm{pg} / \mathrm{ml} / \mathrm{mg}$ ovarian wt.

Table 1. Effect of increasing LH step concentrations on the mean (pg/mg ovarian wt \pm s.e.m.) and percentage increase in oestradiol$17 \beta$ secretion rate over the initial 30 -min culture period

\begin{tabular}{lcc}
\hline & \multicolumn{2}{c}{ Time in culture (min) } \\
\cline { 2 - 3 } Treatment & $30-60$ & $60-90$ \\
\hline 25 ng LH step & $6 \cdot 5 \pm 2 \cdot 4(165 \pm 23 \%)^{*}$ & $7 \cdot 8 \pm 3 \cdot 8(175 \pm 32 \%)$ \\
50 ng LH step & $2 \cdot 6 \pm 0.9(123 \pm 7 \%)^{*}$ & $3 \cdot 8 \pm 0 \cdot 4(132 \pm 11 \%)^{*}$ \\
\hline
\end{tabular}

*Values are significantly greater than oestradiol secretion rates of the first $30 \mathrm{~min}$ of culture $(P \leqslant 0.05)(n=5 /$ group $)$. Mean oestradiol- $17 \beta$ secretion rate for the first $30 \mathrm{~min}$ of culture was $16.2 \pm 5.8 \mathrm{pg} / \mathrm{mg}$ ovarian wt.

\section{Results}

Immature ovaries, exposed to medium supplemented with FSH alone secreted $21 \cdot 6 \pm 2 \cdot 2 \mathrm{pg}$ oestradiol-17//mg ovarian weight $/ \mathrm{h}$. When immature ovaries were immediately exposed to a $50 \mathrm{ng} /$ $\mathrm{ml} \mathrm{LH}$ step, oestradiol- $17 \beta$ secretion increased to $33.0 \pm 4.7 \mathrm{pg} / \mathrm{mg}$ ovarian weight $/ \mathrm{h}(P<0.05)$. The $50 \mathrm{ng} / \mathrm{ml}$ LH step elevated the oestradiol- $17 \beta$ secretion rate within $5 \mathrm{~min}$ (Fig. 1). Oestradiol-17 $\beta$ secretion remained elevated throughout the 1-h culture period (Fig. 1). LH given as a linearly increasing and decreasing ramp did not stimulate oestradiol-17 $\beta$ production over control levels $(21 \cdot 1 \pm 1 \cdot 7 \mathrm{pg} / \mathrm{mg}$ ovarian weight $/ \mathrm{h})(P>0.05)$.

Regardless of whether LH was given as a 25 or $50 \mathrm{ng} / \mathrm{ml}$ LH step function, oestradiol-17 $\beta$. secretion rates were elevated over control values during exposure to LH (i.e. 30-60 min of culture) and after LH was removed from the culture medium (i.e. 60-90 min of culture) $(P<0.05)$ (Table 1). Exposure to a $25 \mathrm{ng} / \mathrm{ml} \mathrm{LH}$ step tended to result in higher oestradiol-17 $\beta$ secretion rates than did the $50 \mathrm{ng} / \mathrm{ml} \mathrm{LH}$ step but this increase was not significantly different. 


\section{Discussion}

In peripubertal rats, $\mathrm{LH}$ is secreted in pulses ranging from a nadir of 20 to a peak of $60 \mathrm{ng} / \mathrm{ml}$ (Urbanski \& Ojeda, 1985b). The present results demonstrate that the ovaries of 30-32-day-old rats respond to $\mathrm{LH}$ stimulation with an increase in oestradiol-17 $\beta$ secretion if $\mathrm{LH}$ is at a concentration between 25 and $50 \mathrm{ng} / \mathrm{ml}$. An increase in oestradiol-17 $\beta$ secretion is not observed if $\mathrm{LH}$ concentration is increased from $25 \mathrm{ng} / \mathrm{ml}$ to $50 \mathrm{ng} / \mathrm{ml}$, even though the ovary is exposed to twice as much $\mathrm{LH}$. Urbanski \& Ojeda (1985a) also failed to obtain a dose-response to LH stimulation at concentrations within the 'physiological' range. These observations clearly indicate that the immature ovary is not responding simply to the amount of LH. Rather, within 'physiologial' levels of LH, the immature ovary appears to detect a 'threshold' concentration of $\mathrm{LH}$ which is required to enhance the secretion of oestradiol-17 $\beta$. Preliminary data indicate that this 'threshold' level is between 12 and $25 \mathrm{ng} \mathrm{LH} / \mathrm{ml}$ (J. J. Peluso, unpublished observation).

The pulsatile pattern of LH secretion appears to be important in stimulating oestradiol-17 $\beta$ secretion from immature ovaries both in vivo (Advis et al., 1979; Andrews \& Ojeda, 1981) and in vitro (Urbanski \& Ojeda, 1985a). Previous studies indicate that the amplitude is a major factor in determining the amount of oestradiol-17 $\beta$ secreted (Urbanski \& Ojeda, 1985a). While the amplitude or 'threshold' is an important factor, the time required to achieve the stimulatory amplitude may play a key role in determining the stimulatory potential of an $\mathrm{LH}$ pulse. Support for this hypothesis can be found from an analysis of Exps I and II. In Exp. I, ovarian oestradiol-17 $\beta$ secretion was not stimulated by a $50 \mathrm{ng} / \mathrm{ml} \mathrm{LH} \mathrm{ramp,} \mathrm{while} \mathrm{a} 50 \mathrm{ng} / \mathrm{ml} \mathrm{LH}$ step promotes a $50 \%$ increase in oestradiol$17 \beta$ secretion. Since both the $50 \mathrm{ng} / \mathrm{ml}$ step and ramp possess the same amount of $\mathrm{LH}(250 \mathrm{ng})$ and the same amplitude (i.e. $50 \mathrm{ng} / \mathrm{ml}$ ), some other factor(s) must account for the different responses obtained from these two types of LH pulses.

The $50 \mathrm{ng} / \mathrm{ml} \mathrm{LH}$ ramp could have failed to stimulate oestradiol-17 $\beta$ secretion because the amplitude of $50 \mathrm{ng} / \mathrm{ml}$ was only maintained for about $5 \mathrm{~min}$ compared to $30 \mathrm{~min}$ in the $50 \mathrm{ng} / \mathrm{ml} \mathrm{LH}$ step. However, LH does not have to be present continuously in order to evoke a stimulatory response. YoungLai (1975) has shown that exposure of isolated rabbit follicles to LH for just $1 \mathrm{sec}$ is sufficient to stimulate and maintain androgen secretion for up to $6 \mathrm{~h}$. Similarly, hCG need only be present for I min to increase carbohydrate metabolism of the prepubertal ovary to the same extent as a 2-h exposure to hCG (Ahren et al., 1971). The observation that the $50 \mathrm{ng} / \mathrm{ml} \mathrm{LH}$ step increases oestradiol- $17 \beta$ secretion rates within 5 min confirms the fact that in the prepubertal ovary LH acts very rapidly to evoke biological responses. Moreover, the data from Exp. II demonstrate that a 30 -min exposure to a $25 \mathrm{ng} \mathrm{LH} / \mathrm{ml}$ is sufficient to stimulate oestradiol- $17 \beta$ secretion rates. Since $\mathrm{LH}$ concentrations are at $25 \mathrm{ng} / \mathrm{ml}$ or greater for $30 \mathrm{~min}$ in the $50 \mathrm{ng} / \mathrm{ml} \mathrm{ramp}$ function, a limited exposure to $\mathrm{LH}$ cannot be used to explain the inability of the $50 \mathrm{ng} / \mathrm{ml} \mathrm{LH}$ ramp to promote oestradiol-17 $\beta$ secretion over control levels.

It could be argued that in the ramp function the $50 \mathrm{ng} \mathrm{LH} / \mathrm{ml}$ concentration is not reached until $30 \mathrm{~min}$ into the perifusion culture, while a $50 \mathrm{ng} \mathrm{LH} / \mathrm{ml}$ concentration is achieved immediately in the $50 \mathrm{ng} / \mathrm{ml} \mathrm{LH}$ step function. During this $30 \mathrm{~min}$ delay, the ovarian tissue could perhaps become less responsive to LH. In Exp. II, LH stimulation was delayed for $30 \mathrm{~min}$ then increased to 25 or $50 \mathrm{ng} / \mathrm{ml}$. These elevated concentrations were maintained for $30 \mathrm{~min}$ then rapidly decreased to $0 \mathrm{ng} / \mathrm{ml}$. Regardless of whether LH was administered as a 25 or $50 \mathrm{ng} / \mathrm{ml} \mathrm{LH}$ step, oestradiol- $17 \beta$ secretion is elevated to the same degree. This observation negates the possibility that the tissue becomes less responsive during perifusion culture without exposure to $\mathbf{L H}$.

The only remaining difference between the $50 \mathrm{ng} / \mathrm{ml} \mathrm{LH}$ step function and the $50 \mathrm{ng} / \mathrm{ml} \mathrm{LH}$ ramp function is the rate at which $\mathrm{LH}$ concentrations increase to a stimulatory amplitude. Both amplitude and the rate at which a secretagogue increases to a stimulatory level are important factors in controlling MSH secretion from pituitary fragments in vitro (Keith et al., 1983). The time required to reach 'threshold' amplitude therefore appears to be a second component of the LH pulse that is necessary to convey a stimulatory action. 
In summary, the data presented in this paper support the concept that it is the pulse characteristics of 'threshold' amplitude and the rate at which the 'threshold' level is reached that are important in controlling oestradiol-17 $\beta$ secretion from immature rat ovaries in vitro and potentially in vivo. Further, since most hormones are secreted in an episodic or pulsatile manner, 'threshold' and the time required to reach a 'threshold' may be universal elements in the mechanism by which hormonal pulses evoke physiological responses from their target tissues in vivo.

The LH and FSH were gifts from the National Pituitary Agency.

\section{References}

Advis, J.P., Andrews, W.W. \& Ojeda, S.R. (1979) Changes in ovarian steroidal and prostaglandin $E$ responsiveness to gonadotropins during the onset of puberty in the female rat. Endocrinology 104, 653-658.

Ahren, K., Hamberger, L. \& Perklev, T. (1971) Rapid interaction between gonadotrophic hormones and the prepubertal rat ovary. Acta physiol. scand. 82, 191-201.

Andrews, W.W. \& Ojeda, S.R. (1981) A detailed analysis of the serum luteinizing hormone secretory profile in conscious, free-moving female rats during the time of puberty. Endocrinology 109, 2032-2039.

D'Amato, C., Calvo, F.O., Stockert, B. \& Bahr, J.M. (1981) Steroid secretion by perifused rabbit follicles: effect of repeated gonadotropin challenges. Biol. Reprod. 25, 843-850.

Gruenberg, M.L., Steger, R.W. \& Peluso, J.J. (1983) Follicular development, steroidogenesis and ovulation within ovaries exposed in vitro to hormone levels which mimic those of the rat estrous cycle. Biol. Reprod. 29, 1265-1275.

Hedin, L., Ekholm, C. \& Hillensjo, T. (1983) Doserelated effects of luteinizing hormone on the pattern of steroidogenesis and cyclic adenosine monophosphate release in superfused preovulatory rat follicles. Biol. Reprod. 29, 895-904.

Keith, D.L., Allen, R.G., Stack, J., Robertson, L.M. \& Kendall, J.W. (1983) Potassium-modulated secretion of immunoreactive melanocyte-stimulating hormone and endorphin from mouse neuro-intermediate lobes. Endocrinology 112, 1886-1889.

Kimura, F. \& Kawakawi, M. (1982) Episodic LH secretion in immature male and female rats as assessed by sequential blood sampling. Neuroendocrinology 35, $128-132$.

Lamprecht, S.A., Kohen, F., Ausher, J., Zor, U. \& Lindner, H.R. (1976) Hormonal stimulation of oestradiol-17 $\beta$ release from the rat ovary during early postnatal development. $J$. Endocr. 68, 343-344.
Meijs-Roelofs, H.M.A., Kramer, P. \& Sander, H.J. (1983) Changes in serum concentration of luteinizing hormone in the female rat approaching puberty. $J$. Endocr. 98, 241-249.

Peluso, J.J., Steger, R.W. \& Hafez, E. (1976) Development of gonadotrophin-binding sites in the immature rat ovary. J. Reprod. Fert. 47, 55-58.

Peluso, J.J., Downey, M.C. \& Gruenberg, M.L. (1984a) Role of LH pulse amplitude in controlling rat ovarian oestradiol-17及 secretion in vitro. J. Reprod. Fert. 71, 107-112.

Peluso, J.J., Gruenberg, M.L. \& Steger, R.W. (1984b) Regulation of ovarian follicular growth and steroidogenesis by low-amplitude LH pulses. Am. J. Physiol. 246, R $184-\mathrm{R} 189$.

Quattropani, S.L. \& Weisz, J. (1973) Conversion of progesterone to estrone and estradiol in vitro by the ovary of the infantile rat in relation to the development of its interstitial tissue. Endocrinology 93, 1269-1276.

Richards, J.S. \& Bogovich, K. (1982) Effects of human chorionic gonadotropin and progesterone on follicular development in the immature rat. Endocrinology 111, 1429-1438.

Uilenbroek, J.Th.J. \& van der Linden, R. (1983) Changes in gonadotropin binding to rat ovaries during sexual maturation. Acta endocr., Copenh. 103, 413419.

Urbanski, H.F. \& Ojeda, S.R. (1985a) In vitro simulation of prepubertal changes in pulsatile luteinizing hormone release enhances progesterone and $17 \beta$-estradiol secretion from immature rat ovaries. Endocrinology $117,638-643$.

Urbanski, H.F. \& Ojeda, S.R. (1985b) The juvenileperipubertal transition period in the female rat: establishment of a diurnal pattern of pulsatile luteinizing hormone secretion. Endocrinology 117, 644-649.

YoungLai, E.V.(1975) Rapid interaction between luteinizing hormone and isolated rabbit follicles. J. Endocr. 67, 289-296. 